\title{
COMMENTS
}

\section{Involuntary Dismissals of Class Actions}

The class action provisions of the Federal Rules of Civil Procedure ${ }^{1}$ attempt to provide an effective means for the protection of rights that would not ordinarily be asserted through individual actions. ${ }^{2}$ The possibility of recovery of large attorney's fees has led to an inundation of the federal courts with class actions, many of which have little merit or are of negligible importance to class members. ${ }^{3}$ The problem currently facing legislatures and courts is to ensure that the rule fulfills its original purpose while at the same time preventing abuse of the class action device.

It has been suggested that the provisions of the rule that deal with compromises and dismissals can play a large part in lessening the strains class actions have placed on the already overburdened federal judiciary. ${ }^{4}$ Rule 23(e) provides: "A class action shall not be dismissed or compromised without the approval of the court and notice of the proposed dismissal or compromise of the class action shall be given to all members of the class in such manner as the court directs."

The vast majority of class actions are disposed of before trial, ${ }^{5}$ by vol-

1 FED. R. Crv. P. 23.

2 See Ford, Federal Rule 23: A Device for Aiding the Small Claimant, 10 B.C. IND. \& COM. L. REv. 501 (1969); Kalven \& Rosenfeld, The Contemporary Function of the Class Suit, 8 U. CHr. L. Rev. 684 (1941); Weinstein, Revision of Procedure: Some Problems in Class Actions, 9 Buffalo L. REv. 433 (1960); Wright, Glass Actions, 47 F.R.D. 169 (1969).

$3 \mathrm{See}$, e.g., the statement of District Judge Weinfeld in Free World Foreign Cars, Inc. v. Alfa Romeo, 55 F.R.D. 26, 30 (S.D.N.Y. 1972): "However, it is not idle to observe that class actions, which have proliferated tremendously since the advent of the current Rule-indeed beyond the expectations of its sponsors-threaten to engulf the courts; that substantial questions have been raised whether the Rule, intended to benefit the small consumer or invstor who otherwise would have no means of redress, has really achieved its promise, or rather whether it has resulted in miniscule recoveries by its intended beneficiaries while lawyers have reaped a golden harvest of fees."

4 Dole, The Settlement of Class Actions for Damages, 71 CoLvm. L. REv. 971,976 (1971). Professor Dole focuses on the role voluntary dismissals could play in the area; this comment examines the problems posed by involuntary dismissals.

5 For example, since 1966 no antitrust or securities class action has proceeded through trial to an actual determination of damages. AmErican Colleger of TrIaL LAWYERs, REPORT and Recommendations of the Spectal Committee on Rule 23 of the Federal Rules of Crvil Procedure 15-16 (1972) [hereinafter cited as REPORT ANd Recommendations]. 
untary or involuntary dismissal. The notice and court approval provisions of rule 23(e), however, have usually been construed as applying only to voluntary dismissals. ${ }^{6}$ Appropriate procedural regulation of involuntary dismissals is essential to the proper functioning of the class action device. This comment examines the legal and practical effects of involuntary dismissals on the interests of class members under present law and evaluates several procedural modifications that would more adequately serve the purposes of rule 23 .

\section{The Procedural Background}

\section{A. Rule 23}

The class action originated in equity as a device enabling the court to proceed to judgment where the parties were too numerous to all be brought before the court. ${ }^{7}$ The first version of rule 23, adopted in 1937, designated three categories as appropriate for class action treatment: where the right sued upon was joint or common to the members of the class; where the rights asserted were several but the relief sought by all members affected the same specific property; and where the rights asserted were several but there was a common question of law or fact and a common type of relief was sought. ${ }^{8}$ These categories were soon denominated "true," "hybrid," and "spurious" class actions respectively. ${ }^{9}$ Only in a "true" class action did the decree rendered have full res judicata effects as to absent members of the class. ${ }^{10}$ The judgment in a "hybrid" class action had limited res judicata effects, ${ }^{11}$ and the judgment in a "spurious" class suit had no binding effects on absent class members. ${ }^{12}$

6 3B J. Moore, Federal, Practice f 23.80 [2.-I],[3] (1969).

7 See J. Story, Commentaries on Equity Pleadings § 95-97 (2d ed. 1840).

8 The simple definition found in the equity rules of when an action might be maintained as a class action was rejected. Equity R. 38, 226 U.S. 659 (1912), provided: "When the question is one of common or general interest to many persons constituting a class so numerous as to make it impracticable to bring them all before the court, one or more may sue or defend for the whole."

9 3B J. MOORE, supra note 6, If 23.02-1.

10 See cases cited id. T 23.11[2].

11 The "hybrid" class action involved situations in which claims were made against specific property. Judgment transferring the property was res judicata, but claims of those not actually parties to the action were not cut off as against the owner of the property. See cases cited id. I 23.11[4].

12 Indeed, a "spurious" class suit was little more than provision for permissive joinder. See cases cited id.23.11[3]. Some courts did take the view that members of the class could intervene after judgment favorable to the class and take under the judgment even though they would not have been bound by an unfavorable judgment. Id. 
The 1966 revision of rule 23 responded to the confusion surrounding classification of cases and the restrictive effect given judgments in "spurious" class actions by rejecting the "true-hybrid-spurious" classification ${ }^{13}$ and specifically providing that a judgment rendered in any class action maintained under the rule is binding on all those the court determines to be members of the class. ${ }^{14}$ The old classifications were replaced with functional definitions of controversies appropriate for class action treatment..$^{15}$ A class action may now be maintained under subdivision $(b)(I)$ of the rule where a risk of inconsistent adjudications exists or where an adjudication of the rights of one party would be dispositive of the interests of other persons. Subdivision (b)(2) allows class actions for injunctive or declaratory relief where such relief is the appropriate remedy for all members of the class. ${ }^{16}$ Class actions are maintainable under subdivision (b)(3) if the court finds that common questions of law or fact predominate over questions affecting only individual members and that a class action is superior to other means for the adjudication of the controversy. The expansion in res judicata effects of "spurious" class actions, generally maintainable as "common question" actions under (b)(3), has been a primary motivation for the increased use of the class action device and the resultant burdens on the federal judiciary. ${ }^{17}$

The relatively slight connection between class members in (b)(3) actions creates the possibility that res judicata effects could be imposed on a class member without his knowledge or acquiescence. To prevent this from occurring, the rule requires that the "best notice practicable" be given to all members of the (b)(3) class, informing them that a class suit is being maintained on their behalf and giving them the opportunity to avoid being bound by a final judgment by opting out of the action if they so desire. ${ }^{18}$ In contrast, the rule does not require any preliminary notice to members of the class in (b)(1) or (b)(2) class suits. ${ }^{19}$

13 The committee noted that the classification had proved "obscure and uncertain." Amendments to Rules of Civil Procedure, 39 F.R.D. 69, 98 (1966).

14 FED. R. Crv. P. 23(c)(3).

15 Amendments To Rules of Civil Procedure, supra note 13, at 99.

16 While (b)(2) actions are mainly civil rights class actions, the Advisory Committee noted that other applications were possible. $I d$. at 102.

17 See REPORT AND RECOMMENDATIONS, supra note 5, at 10-12. This is apparently contrary to the expectations of the Advisory Committee. Compare Kaplan, Continuing Work of the Civil Committee: 1966 Amendments of the Federal Rules of Civil Procedure, 81 HARv. L. Rev. 356, 394-96 (1967) with REPORT AND REcommendations, supra note 5, at 4-6.

18 FED. R. Grv. P. 23(c)(2).

19 The circuits are divided on whether due process requires notice to members of the class in (b)(1) and (b)(2) class actions. Compare Eisen v. Carlisle \& Jacquelin, 391 F.2d 
B. Settlements and Dismissals under Rule 23

The 1937 version of rule 23 provided that a class action could not be dismissed without the approval of the court. This represented an attempt to guard against the collusion and strike-suiting ${ }^{20}$ that had marked the class action device prior to the adoption of the rule, ${ }^{21}$ abuses that had been greatly facilitated by the common holding that a class action would be dismissed at the request of the class representative at any time prior to the entry of a decree affecting the rights of absent parties. ${ }^{22}$ Prior to the rule a plaintiff was free to use the leverage afforded by his purported representation of a class to extract, without regard to the interests of the class, a settlement that would inure to his benefit alone. The original rule 23 , by requiring court approval of settlements and dismissals, did much to correct this situation.

An additional protection was provided by requiring notice to class members when a dismissal or compromise of a "true" class suit, binding on all members of the class, was presented to the court. ${ }^{23}$ By requiring notice of the pending settlement the rule attempted to give the court the benefit of the views of those class members who objected to the settlement. This provision was designed to prevent the named parties from collusively presenting only such information as would lead the court to approve the settlement. The 1966 amendments to rule 23 that made judgments in class actions binding on all class members included a corresponding extension of the requirement of notice of a dismissal or compromise.

As noted earlier, it is generally agreed that the notice and court approval provisions of rule 23(e), like those of its predecessor, are applicable only to voluntary dismissals. ${ }^{24}$ The only justification offered for the exclusion of involuntary dismissals from the safeguards of rule 23(e) is that because involuntary dismissals "presumably could not involve collusion or benefit the representative plaintiffs at the expense of the remaining class members, the protection afforded by giving notice

555, 564-65 (2d Gir. 1968) with Yaffe v. Powers, 454 F.2d 1362, 1366 (1st Gir. 1972) and Fammond v. Powell, 462 F.2d 1053, 1055 (4th Gir. 1972).

20 A strike suit is an action brought not in good faith but in hopes of forcing a settlement for a sum disproportionate to the normal value of the claim through exploitation of the nuisance value of the action.

21 See Note, Extortionate Corporate Litigation: The Strike Suit, 34 CoLum. L. REv. 1308 (1934).

22 See cases cited 3B J. Moore, supra note 6, I 23.80[4]; Annot., 8 A.L.R. 950 (1920).

23 FED. R. Crv. P. 23(c), 308 U.S. 690 (1939). This rule was interpreted to apply only to voluntary dismissals.

24 See, e.g., Pelelas v. Caterpillar Tractor Co., 113 F.2d 629 (7th Cir. 1940); Dologow v. Anderson, 53 F.R.D. 664, 690 (E.D.N.Y. 1971), aff'd, 464 F.2d 437 (2d Cir. 1972); cases cited 3B J. MOORE, supra note 6, If 23.80[3]. 
to absentees is not required."25 This presumption is erroneous. A compromise or settlement can easily be disguised as an involuntary dismissal. Failure to extend the rule to involuntary dismissals thus opens the way to collusion and strike-suiting.

\section{Involuntary Dismissals under the Federal Rules}

Rule 23 makes no special provision for involuntary dismissals of class actions; therefore, the provisions of the federal rules that generally govern involuntary dismissals are applicable. Rule 41 (b) provides in part: "Unless the court in its order of dismissal otherwise specifies, a dismissal under this subdivision and any dismissal not provided for in this rule, other than a dismissal for lack of jurisdiction, for improper venue, or for failure to join a party under rule 19, operates as an adjudication upon the merits." 26 In other words, dismissal is with prejudice unless the court or the rule specifically states otherwise. ${ }^{27}$

Involuntary dismissals may be entered for a number of reasons. For example, rule $41(\mathrm{~b})$ permits involuntary dismissal for failure of the plaintiff to prosecute, and rule 37 grants the court discretionary power to dismiss pursuant to Rule 41 (b) for failure to make discovery. ${ }^{28}$ Rule 41(b) dismissals of class actions that are not specified to be without prejudice conclude the rights of absent class members without providing the safeguards of rule $23(\mathrm{a}){ }^{20}$ This situation raises the question of whether an involuntary dismissal that concludes the rights of absent class members is consistent with established principles of due process.

257 A G. Wright \& A. Miller, Federal Practice and Procedure \& 1797, at 235 (1972).

20 The rule was drafted in this fashion to obviate speculation about the effect of an involuntary dismissal by making it clear that a dismissal is with prejudice unless the court or the rule specifically states otherwise. $5 \mathrm{~J}$. MooRe, supra note 6, If 41.14[1] (1971).

27 The specific exemption in the rule of dismissals for lack of jurisdiction has been construed by the Supreme Court "as encompassing those dismissals which are based on a plaintiff's failure to comply with a precondition requisite to the Court's going forward to determine the merits of his substantive claims." Costello v. United States, 365 U.S. 265, 285 (1961). The rule was thus made to conform to the general principle previously established by the Court that an involuntary dismissal does not bar a subsequent action if it is grounded on some matter preliminary to a consideration of the merits by the court. Swift v. McPherson, 232 U.S. 51, 56 (1914); Hughes v. United States, 71 U.S. (4 Wall.) 232, 237 (1866). For application of this rule in a class action context, see Saylor v. Lindsley, 391 F.2d 965 (2d Cir. 1968). A dismissal of a suit brought as a class action for failure to satisfy the prerequistes of subdivisions (a) and (b) necessary for certification of a class action, being on a matter preliminary to consideration of the merits, must, therefore, be without prejudice to the rights of the purported class.

28 FED. R. CIv. P. 37(b)(2)(C) provides that an action may, in the discretion of the court, be dismissed for failure to comply with court-ordered discovery. FED. R. Grv. P. 37(d) provides a like discretionary sanction for failure to make discovery that may be requested without court approval.

29 See text and notes at notes 30-65 infra. 
II. Constitutional Issues Raised by Involuntary Dismissals of Glass Actions

\section{A. Adequacy of Representation}

It is an established rule of due process that in order for a person to be bound by the judgment of a court he must be brought before the court and made a party to the action..$^{30}$ Class actions are an exception to this general rule. ${ }^{31}$ Not all members of the class need be brought before the court, but if absent members are to be bound by the judgment, established principles of due process require that their interests be adequately represented.32 In Smith $v$. Swormsted $t^{33}$ the Supreme Court stated that "where ... a few are permitted to sue and defend on behalf of the many, by representation, care must be taken that persons are brought on the record fairly representing the interest or right involved, so that it may be fully and honestly tried." 34 Rule 23 incorporates this due process standard by demanding, as a prerequisite to class action status, a court determination that the representative will adequately represent absent class members. ${ }^{35}$

Adequacy of representation requires both competent counsel and a class representative who will vigorously prosecute class claims. ${ }^{36}$ The requirement of competence of chosen counsel is satisfied if he is "qualified, experienced, and generally able to conduct the proposed litigation." 37 Inquiry into the quality of the representation that will be provided by the representative himself is more extensive. ${ }^{38}$

1. The Representative Party. The basic criterion of representation is "the forthrightness and vigor with which the representative party can be expected to assert and defend the interests of the members of the class so as to assure them due process." 39 Involuntary dismissals generally create doubts concerning the zeal with which the interests of the plaintiff class have been pursued by the representative.

30 Postal Telegraph Cable Co. v. Newport, 247 U.S. 464 (1918); Old Wayne Mutual Life Ass'n v. McDonough, 204 U.S. 8 (1907); Pennoyer v. Neff, 95 U.S. 714 (1877).

31 Hansberry v. Lee, 311 U.S. 32 (1940); Christopher v. Brusselback, 302 U.S. 500 (1938); Supreme Tribe of Ben-Hur v. Cauble, 255 U.S. 356 (1921); Hartford Life Ins. Co. v. Ibs, 237 U.S. 662 (1915); Smith v. Swormstedt, 57 U.S. (16 How.) 188 (1853).

32 Sam Fox Publishing Co. v. United States, 366 U.S. 683, 691-92 (1961); Hansberry v. Lee, 311 U.S. 32, $41-42$ (1940); Supreme Tribe of Ben-Hur v. Cauble, 255 U.S. 356, 367 (1921); Smith v. Swormstedt, 57 U.S. (16 How.) 288, 303 (1853).

3357 U.S. (16 How.) 288 (1853).

34 Id. at 303 .

35 Fed. R. CIV. P. 23(a)(4).

36 See cases cited 7 C. WRIGHT \& A. Micler, supra note 25, § 1766, at 632-33 (1972).

37 Eisen v. Carlisle \& Jacquelin, 391 F.2d 555, 562 (2d Cir. 1968).

38 See 7 C. WRIGHT \& A. MrLLER, supra note 25, §\$ 1766-71.

39 Mersay v. First Republic Corp. of America, 43 F.R.D. 465, 470 (S.D.N.Y. 1968). 
In a recent case, Papilsky v. Berndt, ${ }^{40}$ the Second Circuit was confronted with many of the questions raised by the involuntary dismissal of a class action. An earlier stockholder's derivative action on the same claim, White of Bernstein $v$. Driscoll, 41 had been dismissed for failure to answer interrogatories. The defendants in Papilsky sought summary judgment arguing that, because the dismissal in White had not been stated to be without prejudice and the Papilsky plaintiff had been a member of the class represented in White, rules 37 and $41(\mathrm{~b})$ rendered the White dismissal a decision on the merits and res judicata as to the plaintiff in Papilsky. The Second Circuit affirmed the district court's denial of summary judgment by carving out an exception to the general principles of rule $41(\mathrm{~b})$ "for derivative suits dismissed for failure to answer interrogatories." 42 After a lengthy discussion of the reasons for requiring notice of involuntary dismissals of class actions, the court stated that "[a] dismissal for failure to answer interrogatories cannot accurately be characterized as either a voluntary dismissal or a dismissal following a hearing on the merits." 43 The court admitted that a dismissal for failure to answer interrogatories has some of the attributes of an adjudication on the merits, but "on balance," it viewed such dismissals as "more analogous to voluntary dismissals." 44 The court therefore concluded that notice of the dismissal should have been given to nonparty class members and that a judgment without such notice was not binding on absent class members.

The decision in Papilsky was technically based on the failure to give notice of a "voluntary" dismissal. The motivation behind the decision, however, may be indicated by the court's concern that "a dismissal for failure to answer interrogatories could easily disguise a collusive settlement," 45 and that a "fainthearted" plaintiff could prejudice the interests of the entire class. ${ }^{46}$ The court specifically noted the special master's finding in White that the plaintiffs were "not serious in prosecuting [the] action ..."47 and a First Circuit decision ${ }^{48}$ holding that facts

40466 F.2d 251 (1972). This was a stockholders' derivative action under FED. R. Crv. P. 23.1; the language of rule 23.1 dealing with dismissals is identical to that of rule 23 and courts have employed the same standards in dealing with dismissals under both rules.

41 Civil No. 67-98 (S.D.N.Y., filed Dec. 9, 1968).

42466 F.2d at 256.

13 Id. at 259.

44 Id.

45 Id. The court's footnote to this statement, disclaiming any inference of wrongdoing by the White plaintiffs, is unconvincing in light of its overall concern with collusive settlements.

$46 I d$. at 258.

47 Id. at 260.

48 Moses v. Burgin, 445 F.2d 369 (1st Cir.), cert. denied, 404 U.S. 994 (1971). 
similar to those alleged in White were violations of the federal securities laws and created a right of recovery. The court's conclusion that the White dismissal was more voluntary than involuntary thus seems to be based on its concern for the adequacy of representation involved. A class representative who enters into a collusive settlement with the defendant or faintheartedly prosecutes a colorable claim is clearly not an adequate representative. To dismiss a class suit with prejudice to the class under such circumstances would constitute a denial of due process.

An examination of the assumptions used to justify dismissals with prejudice for failure to make discovery in other than class actions demonstrates the validity of the result reached in Papilsky. In an early case, Hammond Packing Co. v. Arkansas, ${ }^{49}$ the Supreme Court held that entry of a default judgment against a defendant for his failure to make discovery was not a denial of due process. The Court relied on "the undoubted right" of the lawmaking power to create a presumption of fact as to the bad faith and untruth of an answer begotten from the suppression or failure to produce the proof ordered, when such proof concerned the rightful decision of the cause." 50 Later, in Societe Internationale v. Rogers, ${ }^{51}$ however, the Court recognized that this presumed lack of merit might not be sustainable where a plaintiff's good faith efforts to produce the information requested had failed: "[W]e think that Rule 37 should not be construed to authorize dismissal of the complaint because of petitioner's noncompliance with a pretrial production order when it has been established that failure to comply has been due to inability, and not to willfulness, bad faith, or any fault of petitioner."52

It is difficult to justify an involuntary dismissal of a class action with prejudice on the ground of "willfulness, bad faith, or any fault" of the absent members of the represented class or presumed want of merit in the claim presented. There is little opportunity for "willfulness, bad faith, or any fault" on their part; 53 absent members of the class in the

49212 U.S. 322 (1909).

$50 \mathrm{Id}$. at $350-51$.

51357 U.S. 197 (1958).

62 Id. at 212.

53 This is not the problem posed in Brennan v. Midwestern United Life Ins. Co., 450 F.2d 999 (7th Gir. 1971). There, interrogatories were directed not solely to the class representative but to all members of the class, approximately 600 persons; the Seventh Circuit sustained dismissals with prejudice as to those class members who had failed to answer the propounded interrogatories. The decision is highly questionable; it allows a defendant to intimidate class members by seeking extensive discovery, perhaps thereby forcing them from the action. See Wainwright v. Kraftco Corp., 54 F.R.D. 532 (N.D. Ga. 1972); Note, Civil Procedure: Absentee Class Members Subjected to Discovery and Claims Dismissed 
vast majority of cases would not even know that discovery procedures were being utilized. Nor can an automatic presumption of want of merit be created to sustain such a dismissal; rather, as was implied by the Second Circuit in Papilsky, the dismissal of a colorable claim must be attributed to either faintheartedness or collusion on the part of the class representative. As the Second Circuit stated in Trans World Airlines, Inc. v. Hughes: "[T] he totality of the circumstances surrounding the failure to make discovery must be considered in determining what sanctions to apply ... ." ${ }^{4}$ In the "totality of the circumstances" presented by the ordinary class action, a dismissal with prejudice for failure to make discovery, however applicable it might be to the class representative, cannot be justified when applied to the members of the class. Such a dismissal, where the claim is at least colorable, presents a prima facie case of inadequate representation. The situation is thus analogous to that presented in Societe Internationale and similar due process considerations require the same refusal to utilize the presumptions of lack of merit or bad faith. To apply these presumptions in the context of a dismissal of a class action for failure to make discovery would be to destroy the protection of the rights of absent class members that the due process-adequacy of representation standard was designed to establish.

Dismissals of class actions for want of prosecution present the courts with similar problems. Two cases, both of some antiquity, reveal the tension between the special needs of class actions and the court's traditional ability to keep its docket clear of unprosecuted actions.

In Partridge v. St. Louis Joint Stock Land Bank $k^{55}$ the court dismissed a class action that had been on its docket for nine years without any action being taken in its prosecution. The court did not indicate the effect that dismissal would have on subsequent actions brought on the same claim, but the predecessor of rule 23(e), requiring notice for dismissals, was held "not applicable to dismissals for failure to prosecute under the circumstances here presented." 56 Nor was it applied in National Hairdressers' \& Cosmetologists' Association v. Philad Co., ${ }^{57}$ in which a class action was dismissed pursuant to a district court rule permitting dismissal of an action as of course without prejudice if no steps were taken

for Failure to Respond, 1971 Duke L.J. 1007. A more proper view would be to regard the class representative as having voluntarily assumed the responsibility of providing whatever information the defendant may seek from members of the purported class. This appears to be the approach taken by the court in Wainwright.

54449 F.2d 51, 57 (1971), rev'd on other grounds sub nom., Hughes Tool Co. v. Trans World Airlines, Inc., 409 U.S. 363 (1973).

55130 F.2d 281 (8th Cir. 1942).

56 Id. at 286.

674 F.R.D. 106 (D. Del. 1944). 
in its prosecution for one year. The court stated that the notice provisions of the predecessor of rule 23(e) were paramount to the local district court rule but would not be applied "under the circumstances" of the case. ${ }^{.58}$ The suit had been brought to obtain a declaratory judgment and to restrain the defendant from collecting license fees it claimed under a patent; the claim had become moot, however, due to the defendant's earlier sale of the patent under an order of the court. These circumstances clearly justified the dismissal without notice. The issue in $\mathrm{Na}$ tional Hairdressers' was mooted not by collusion or a secret settlement but rather because of an order of the court itself. The dismissal in Partridge is more troublesome. Although the only protest against the dismissal of that case came from the representative whose laxity had allowed the action to linger on the docket for nine years and it appeared that the action had been brought merely for purposes of harassment, the decision may be criticized as not sufficiently safeguarding the rights of absent class members. The fact that no members of the class appeared to protest the dismissal may not be viewed as indicating a lack of interest on the part of class members, because no notice of the dismissal was given. Further, class member reliance on prosecution of the class action may explain the fact that no one intervened to press the action or brought another action on the same claim during the time that the suit lay dormant on the docket; this argument is, of course, more compelling when applied to cases involving shorter periods of nonprosecution. Dismissal for failure to prosecute may indicate that the representative has lost interest in the action or may be an intentional attempt to avoid the safeguards established by rule 23(e); in both cases care must be taken to avoid prejudice to the rights of absent class members.

The majority of the federal district courts have adopted rules requiring that, in the absence of good cause to the contrary, an action be dismissed if there has been no prosecution of the action within a stated period of time. ${ }^{59}$ Nearly all dismissals made under these rules are with prejudice unless the court specifically states otherwise, and no provision is made for notice to absent class members. ${ }^{60}$ Such rules provide insufficient protection for the interests of absent class members.

58 Id. at 107. Compare Daugherty v. Ball, 43 F.R.D. 329 (C.D. Cal. 1967) where a class suit was dismissed with prejudice on a finding of mootness; rule 23(e) was not applied.

59 See, e.g., D. Ariz. R. 38(d) (I year); C.D. Cal. R. 10 (1 year; specified to be without prejudice); S.D. Fla. R. 13 (3 months); N.D. III. R. 21(a) (6 months); D. Mass. R. 22 (2 years); D. Neb. R. 18 (1 year); S.D.N.Y. R. 23 (1 year); W.D. Tenn. R. 14 (1 year; specified to be without prejudice).

60 The notice that is required by nearly all the local rules goes to the named party, here the class representative, or to the attorney only. See, e.g., rules cited note 59 supra. 
The principles behind dismissals with prejudice for want of prosecution were recently approved in Costello v. United States: ${ }^{61}$

All of the dismissals enumerated in Rule $41(\mathrm{~b})$ which operate as adjudications on the merits-failure of the plaintiff to prosecute, or to comply with an order of the Court, or to present evidence showing a right to the relief on the facts and the law-primarily involve situations in which the defendant must incur the inconvenience of preparing to meet the merits because there is no initial bar to the Court's reaching them. It is therefore logical that a dismissal on one of these grounds should, unless the Court otherwise specifies, bar a subsequent action. ${ }^{62}$

This rationale, however, will not withstand analysis in the class action context.

Where a dismissal for want of prosecution of a colorable class action claim may be presumed to be the product of collusive action on the part of the defendant, he cannot be heard to object that he has been forced to prepare to defend on the merits. On the other hand, where such a dismissal is the result of bad faith or faintheartedness on the part of the class representative, the absent members have been inadequately represented and a dismissal with prejudice would be a denial of due process.

Situations in which the adequacy of representation provided by the representative is dubious are certainly not limited to those discussed above. Other examples include failure to present evidence and failure to oppose a motion for summary judgment. ${ }^{63}$ Where an involuntary dismissal of a class action is due to the failure of the representative to properly represent absent class members, it will generally be improper for the court to order or allow the dismissal to be with prejudice to any but the named representative.

2. The Class Attorney. Inquiry into the adequacy of representation of the class focuses not only on the character of the representation provided by the class representative but also on that of the attorney he has selected. It is necessary to inquire whether different considerations apply where the involuntary dismissal results not from a failing of the

61 365 U.S. 265 (1961).

62 Id. at 286.

63 Note that failure to appeal has been held to render the representation provided inadequate. Gonzales v. Cassidy, 474 F.2d 67 (5th Cir. 1973). Compare this decision with Young v. Higbee Co., 324 U.S. 204 (1945), discussed in text at notes 87-88 infra. But see Research Corp. v. Pfister Assoc. Growers, Inc., 301 F. Supp. 497 (N.D. Ill. 1969), where it was held, in patent and antitrust actions against a defendant class, that the named defendant would provide adequate representation for the class despite his expressed "desire" not to serve as a representative of the class. 
class representative but rather from the inexcusable neglect of the counsel he has retained.

Federal Rule of Givil Procedure 60(b)(1) provides that a party may be relieved from a final judgment for "mistake, inadvertence, surprise or excusable neglect" on motion made within a reasonable time not to exceed one year after entry of judgment. Rule $60(\mathrm{~b})(6)$ provides that a party may be relieved from judgment for "any other reason justifying relief from the operation of the judgment." A motion under rule $60(\mathrm{~b})(6)$ need only be made "within a reasonable time." The scope of these remedies, however, was severely restricted by the Supreme Court in Link v. Wabash Railroad Co., ${ }^{64}$ in which the Court stated:

There is certainly no merit to the contention that the dismissal of petitioner's claim because of his counsel's unexcused conduct imposes an unjust penalty on the client. Petitioner voluntarily chose this attorney as his representative in the action, and he cannot now avoid the consequences of the acts or omissions of this freely selected agent. Any other notion would be wholly inconsistent with our system of representative litigation, in which each party is deemed bound by the acts of his lawyer-agent ...."65

Although rule $60(\mathrm{~b})$ generally vests a high degree of discretion in the court, ${ }^{66}$ the decision in Link seems to foreclose relief from judgment under rule $60(\mathrm{~b})(1)$ based on the inexcusable neglect of a party's attorney ${ }^{67}$

The rationale of $L i n k$, however, is inapplicable to the ordinary class action. Absent members of the class generally have not voluntarily selected the attorney who will represent them nor will they be in a position to exercise control over the course of the litigation. The principle

64370 U.S. 626 (1962).

65 Id. at 633-34.

66 See cases cited in $7 \mathrm{~J}$. Moore, supra note 6, I 60.19 (1972).

67 Some courts have acted to protect clients from the inexcusable neglect of their attorneys by utilizing rule $60(\mathrm{~b})(6)$, thus circumventing the restrictions imposed on rule 60(b)(1) by Link. See L.P. Steuart, Inc. v. Matthews, 329 F.2d 234 (D.C. Cir. 1964); Transport Pool Div. of Container Leasing, Inc. v. Joe Jones Trucking Co., 319 F. Supp. 1308 (N.D. Ga. 1970); King v. Mordowanec, 46 F.R.D. 474 (D.R.I. 1969). Rule 60(b)(6), unlike rule $60(b)(1)$, imposes no time limit for the motion. These courts have held that the inexcusable neglect appropriate to a $60(\mathrm{~b})(6)$ motion is not the "excusable neglect" of $60(\mathrm{~b})(1)$ and that rule $60(b)(6)$ may therefore be invoked where rule $60(b)(1)$ may not. This interpretation manages to comply with the Supreme Court's holding in Klapprott v. United States, 335 U.S. 601 (1949), that rule 60(b)(6) applies only to those circumstances not covered by the other five subdivisions of rule $60(\mathrm{~b})$. Although it has been suggested that the proper remedy in such a situation is a malpractice suit against the inexcusably neglectful attorney, see Schwarz v. United States, 384 F.2d 833 (2d Cir. 1967), these courts have strained to provide relief from judgment through rule $60(\mathrm{~b})(6)$. 
of voluntary choice on which the rule in $L i n k$ was based thus cannot be sustained.

Notice to members of the class that a class action is being maintained on their behalf provides greater opportunity for their participation in the action; it is not, however, a sufficient basis for the invocation of the Link rule. It might be argued that failure to take action protesting the choice of counsel by the class representative after notice is a sufficiently voluntary choice of counsel by the class members to make the excusable neglect of counsel binding on them. Absent a specific inquiry as to the class member's opinions of named counsel, however, failure to respond to notice cannot be viewed as dispositive. It cannot generally be expected that, even with notice, the adequacy of representation afforded by named counsel will be given more than a cursory examination by the absent class members. More significantly, turning the passive acquiesence of class members in the counsel retained by the representative into the voluntary selection required by $\operatorname{Link}$ would clearly do violence to the theory underlying rule 23 . The rule is intended to provide a means for the vindication of the rights of small claimants who cannot be expected to use their own resources to retain counsel and enter an appearance. In view of the generally small size of the individual claims and the limited resources of the claimants, no investigation or positive acceptance of the attorney selected by the class representative may properly be presumed. ${ }^{68}$

The fact that the court has examined the quality of representation provided by the class attorney in certifying the action as a class action does not furnish a basis for extending the Link principle to class actions. Approval by the court is not the voluntary choice demanded by Link; the Link choice must be made by the class, not for the class.

Involuntary dismissals with prejudice that are based on the conduct of the attorney, like those based upon the failings of the class representative, cannot be justified in the class action situation by any of the theories used to justify such dismissals in ordinary actions. Involuntary

68 For the same reasons Link should not be applied in two other situations in which class members cannot realistically be expected to have examined the representation furnished by the named attorney: first, where affirmative action on the part of class members has been required in order for them to become members of the class, see Iowa $\mathrm{v}$, Union Asphalt \& Roadoils, Inc., 281 F. Supp. 391 (S.D. Iowa 1968); Minnesota v. United States Steel Corp., 44 F.R.D. 559 (D. Minn. 1968); Philadelphia Elec. Co. v. Anaconda American Brass Co., 43 F.R.D. 452 (E.D. Pa. 1968); second, where a court has exercised its power under rule $23(d)(2)$ to send notice designed to ensure that the representative party will provide adequate representation, see Iowa v. Union Asphalt \& Roadoils, Inc., supra; Siegel v. Chicken Delight, Inc., 271 F. Supp. 722 (N.D. Cal. 1967); Kronenberg v. Hotel Governor Clinton, Inc., 41 F.R.D. 42 (S.D.N.Y. 1966). 
dismissals with prejudice should therefore not be permitted in class actions.

\section{B. Statutes of Limitations}

Creation of a system that does not permit involuntary dismissals of class actions with prejudice to the interests of absent class members, however, will not eliminate all due process problems. The running of a statute of limitations may unfairly eliminate the ability of absent class members to assert their claims or diminish the time available for them to act. ${ }^{69}$ Where notice of the maintenance of the class suit has been received, either officially or unofficially, class members may rely on the suit being prosecuted on their behalf and not bring actions of their own. If the statute of limitations has run prior to the involuntary dismissal of the class action, or to the time that the dismissal is brought to the attention of absent class members, the statute may bar any further claims by the class members. This problem is exacerbated by the extended length of time often required to determine if an action may in fact be maintained as a class action. ${ }^{70}$

The filing of an action found to be properly maintainable as a class suit is generally held to toll the statute of limitations as to absent class members. ${ }^{71}$ The involuntary dismissal of a class suit-even when it is

69 The Ninth Gircuit avoided the statute of limitations problem in Utah v. American Pipe \& Constr. Co., 473 F.2d 580 (1972), cert. granted, 41 U.S.L.W. 3594 (U.S. May 7, 1973), by holding that because the representative's class action count had placed the individual claims of members of the class before the court, the class members could file and prosecute their claims individually, even though the class action was dismissed by the district court as inferior to other methods of adjudication, 49 F.R.D. 17 (C.D. Cal. 1969), after the statute of limitations on the claims had run. In an earlier unreported opinion in the same case (copy on file at The University of Chicago Law Review) the Ninth Circuit emphasized that the members of the class had relied upon the class action by not bringing their own separate actions, saying that to employ the stricter standard of reliance adopted by the district court "seems unreasonably to discourage reliance on class actions." This opinion was withdrawn and the reported opinion issued with all mention of reliance contained in the earlier opinion eliminated without explanation.

70 See, e.g., Rothman v. Gould, 52 F.R.D. 494 (S.D.N.Y. 1971), where over two years passed between the filing of the action and the determination that it could be maintained as a class action. Such delays are clearly contrary to the requirement that such determinations be made "as soon as possible." FED. R. Crv. P. 23(c)(1).

71 See Minnesota v. United States Steel Corp., 44 F.R.D. 559, 573-74 (D. Minn. 1968); Philadelphia Elec. Co. v. Anaconda American Brass Co., 43 F.R.D. 452, 460-61 (E.D. Pa. 1968). But see P.W. Husserl, Inc. v. Newman, 25 F.R.D. 264 (S.D.N.Y. 1960); Athas v. Day, 161 F. Supp. 916 (D. Colo. 1958). When the statute may already have run as to some of the absent class members, filing the suit as a class action does not enable them to assert whatever claims they might have. See Slack v. Stiner, 358 F.2d 65 (5th Cir. 1965). See also Zeigler v. Gibralter Life Ins Co. of America, 43 F.R.D. 169, 173 (D.S.D. 1967). It has been suggested that whether a particular statute of limitations will be tolled by the filing of a class suit should be determined by balancing the policies underlying the statute of limitations and those underlying the rule. Comment, Class Actions under New Rule 23 and 
expressly stated that the dismissal is without prejudice-will reactivate the running of the statute of limitations. ${ }^{72}$ Class members who have refrained from bringing their own actions and relied on the prosecution of the class suit may be caught unaware by the running of the statute and foreclosed from asserting claims they would otherwise have pursued.

Due process principles and the policies underlying rule 23 converge to suggest that some type of action be taken to provide affirmative protection for the claims of absent class members. The general standard by which the courts are to be guided has been previously articulated as "due regard [for] the nature of the proceeding and the character of the rights which may be affected by it."73

\section{A Problem of Remedies}

There appear to be four alternatives available to eliminate the problems of providing due process for absent class members where a class suit has been involuntarily dismissed, technically without prejudice. First, the action could be retained on the court's docket, thus holding it perpetually open for intervention. Second, a procedure that would allow proof of reliance on a pending class suit to toll the statute could be adopted. Third, the class representative could be compelled to continue to press the action. Finally, notice of the involuntary dismissal could be required and some time period after the sending of notice provided for the filing of actions. These four alternatives must be examined in the light of their effect on the interests of both class members and defendants and on attempts at strike-suiting and collusive settlements.

\section{A. Retention on the Docket of the Court}

Retention of an action on the docket of the court, thus providing an opportunity for intervention by class members, offers a seemingly at-

Federal Statutes of Limitation: A Study of Conflicting Rationale, 13 VILL. L. REv, 370 (1968).

72 Many states have saving statutes that provide that after an action is dismissed the statute of limitations will not begin to run until after a period allotted, usually six months or one year, for the bringing of a new action has expired. See generally 51 AM. Jur. 2D, Limitation of Actions \$\$ 301-08 (1970). See also Rheingold, Solving Statutes of Limitation Problems, 4 AM. JUR. Triars 441, 612-13 Fig. 12 (1966), for map showing the savings statutes of the various states. Federal courts sitting in diversity cases apply state saving statutes and statutes of limitations. Where there is no federal limitation period to a federal cause of action, federal courts apply state limitation periods and saving statutes. Where there is a federal cause of action with a built-in statute of limitations, state saving statutes cannot be applied; there seem to be no federal saving statutes. 51 AM. JUR. 2D Limitation of Actions $\$ \S 73-74$ (1970); Rheingold, supra, $\S \$ 42,56$.

73 Dohany v. Rogers, 281 U.S. 362, 369 (1930). 
tractive approach. It is doubtful, however, that such action would be effective in the absence of notice to class members. The courts may rely on the initiative of class members to produce further prosecution of their claims, but to the extent that class members continue to rely on the existence of the class suit such further prosecution will not occur.

In addition, such a procedure would clearly impose heavy burdens on defendants. Even if a separate court calendar free of regular docket calls could be established, ${ }^{74}$ the difficulties that statutes of limitations were designed to prevent would be perpetuated. As stated by the Supreme Court in Order of Railroad Telegraphers v. Railway Express Agency, Inc.:

Statutes of limitation, like the equitable doctrine of laches, in their conclusive effects are designed to promote justice by preventing surprises through the revival of claims that have been allowed to slumber until evidence has been lost, memories have faded, and witnesses have disappeared. The theory is that even if one has a just claim it is unjust not to put the adversary on notice to defend within the period of limitation and that the right to be free of stale claims in time comes to prevail over the right to prosecute them. ${ }^{75}$

Indefinite retention on the docket would encourage, rather than prevent, "surprises" and revival of claims after evidence has been lost. These difficulties alone are a sufficient ground upon which to reject such a remedy.

\section{B. Proof of Reliance}

A second alternative would be to allow an absent class member to file an action despite the running of the statute of limitations where he could show that his failure to bring a timely action was due to his reliance on the maintenance of the class suit. ${ }^{6}$ This approach has several serious defects. First, members of the class cannot always be expected to act promptly and the defendant is therefore subjected to the hazards noted above by the Supreme Court in the Telegraphers case. ${ }^{77}$ Second, the issue of whether the class member truly relied would in many cases be difficult to resolve. The necessity of proving reliance might prove a substantial barrier to the prosecution of class members' claims, and add to the burdens on an already overworked federal judiciary.

74 Cf. REPORT AND RECOMMENDATIONS, supra note 5 , at 37.

T5 321 U.S. 342, 348-49 (1944).

76 This approach was suggested by the district court in Philadelphia Elec. Co. v. Anaconda American Brass Co., 43 F.R.D. 452, 460-61 (E.D. Pa. 1968).

77 See text and notes at notes 75-76 supra. 


\section{Compelling Prosecution}

Several courts have refused to permit a plaintiff who has presented a class claim to dismiss that claim where the dismissal represents a deliberate attempt to avoid the notice and court approval provisions of rule 23(e). ${ }^{78}$ In Yaffe v. Detroit Steel Co., ${ }^{79}$ for example, the court refused to permit the class representative to amend his pleadings ${ }^{80}$ to eliminate all references to the class action. The court, holding that rule 23(e) applied regardless of the provisions of rule. 15(a), required, as a prerequisite to the amendment, that the plaintiff give notice to members of the class of the settlement that had led to the attempt to amend the pleadings.

It has also been held that, even where there is no bad faith on the part of the representative, a class suit cannot be dismissed or modified because the class representative has assumed a special status by his allegation of class representation and has bound himself to represent the interests of the entire class. In Sheffield $v$. Board of Supervisors, ${ }^{81}$ the class plaintiff in a federal voting rights suit decided that he desired a different result than that originally sought; nevertheless, he was denied leave to dismiss his complaint. Although the court failed to indicate that the plaintiff would be compelled to continue to prosecute the action, it relied on the proposition that the class representative had assumed a special status by virtue of his presenting a claim on behalf of a class-indicating that he had become a "private attorney general." However salutary the "private attorney general" concept may be in some areas, ${ }^{82}$ it is misused if invoked to compel continued prosecution of a class action. ${ }^{83}$ Although the concept was implicitly relied upon by

78 Rothman v. Gould, 52 F.R.D. 494 (S.D.N.Y. 1971); Philadelphia Elec. Co. v. Anaconda American Brass Co., 43 F.R.D. 324 (E.D. Pa. 1967). But see Saltzman v. Technicolor, Inc., 51 F.R.D. 178 (S.D.N.Y. 1970), where the court implied that it would have dismissed the class claims presented, with prejudice, on motion of the class representative after he had attained his individual goals in the litigation, if it had had before it sufficient information to assess the viability of the class claims.

7950 F.R.D. 481 (N.D. Ill. 1970).

80 The plaintiff would normally have come under Rule 15(a) which provides: "A party may amend his pleading once as a matter of course at any time before a responsive pleading is served ...."

81439 F.2d 35 (5th Cir. 1971).

82 The phrase originated in Judge Frank's opinion in Associated Indus. of New York, Inc., v. Ickes, 134 F.2d 694, 704 (2d Cir. 1943). There the question was one of standing to challenge administrative action, and the "private attorney general" concept was used to confer standing on a party injured by that action.

83 The "private attorney general" concept was endorsed by the Supreme Court in Newman v. Piggie Park Enterprises, Inc., 390 U.S. 400 (1968). There the Court remarked that a plaintiff by bringing a civil rights class action had designated himself a " private 
the court in Sheffield, ${ }^{84}$ it raises significant due process problems; whether the class in such circumstances would be afforded adequate representation seems dubious indeed.

Few courts have discussed what is to occur once dismissal has been denied. ${ }^{85}$ The courts seem to have proceeded on the assumption that a settlement will be negotiated for the entire class. The alternative of compelling prosecution in spite of the faintheartedness or presumed bad faith of the class representative is properly rejected. In such circumstances, the vigor and loyalty with which the original representative would assert the interests of the class is very doubtful.

An instructive case is Young v. Higbee Co ${ }^{86}$ In that case, although no formal class claim was made, an action by two preferred shareholders contesting a plan of reorganization under the Bankruptcy Act, if successful, would have benefited the entire class of preferred shareholders. The two plaintiffs sold their stock at a favorable price to two junior claimants and agreed to discontinue their prosecution of an appeal. The Supreme Court noted that the statute was designed to enable the interests of an entire group to be asserted by one representative, but, more significantly, the Court also found that " $[t]$ he statute neither compels them to appeal nor to prosecute an appeal already taken contrary to their own interests ... ." 87 Despite the "private attorney general" dicta found in some cases, the prosecution of a class action by an unwilling representative must be rejected as an improper safeguard of the interests of absent class members. Even if adequacy of representation problems are put aside, it is difficult to see how a class representative who has become a "private attorney general" can be compelled to continue to prosecute the suit. The only means available would seem to be through use of the contempt powers of the court. It is difficult to imagine a procedure that would do more to discourage the bringing of meritorious class suits than creating an awareness on the part of the

attorney general,' vindicating a policy that Congress considered of the highest priority." Id. at 402. The question there presented, however, was whether the class representative was entitled to recover attorney's fees and did not at all go to whether a class plaintiff must continue to press a class action.

84 The court said, " $[\mathrm{H}]$ aving instituted a public lawsuit to secure rectification for a constitutional wrong of wide dimension, they [the plaintiffs] cannot privately determine its destiny." 439 F.2d 35, 36 (5th Cir. 1971).

85 Responding to the problems presented by such action, the court in Rothman v. Gould, 52 F.R.D. 494 (S.D.N.Y. 1971), found that the representatives who had taken such action had indicated their incapacity to provide adequate representation and required published notice to produce intervenors who might continue to prosecute the action. Rothman is discussed more fully in the text and notes at notes 91-99 infra.

86324 U.S. 204 (1945).

87 Id. at 212. 
putative class representative that he might be compelled, under threat of contempt, and at substantial costs to himself, to prosecute an action merely because he had brought suit as a representative of a class.

\section{Notice}

When considering notice as a possible solution to the dilemma posed by involuntary dismissals it is necessary to note that the focus of the solution should not be to apprise every class member of the involuntary dismissal but rather to secure adequate protection for the rights of the class by providing, as far as possible, a representative who will prosecute the action with the vigor and loyalty that due process demands.

It is to be expected that where an attempt is made to circumvent rule $23(\mathrm{e})$ settlement will occur prior to certification and the concomitant notice that a class suit is being maintained. ${ }^{88}$ Courts have assumed that a suit in which a class claim is made is to be treated as a class suit for purposes of rule 23 (e) when voluntarily dismissed or compromised. ${ }^{89}$ The formality of certification has thus been treated as not controlling. Where an involuntary dismissal would occur before certification the same assumptions should be made.

The attempt at dismissal in Rothman $v$. Gould ${ }^{90}$ came prior to certification of the action as a class action. There the class representative asserted claims under the Securities Exchange Act of 1934 arising out of the manipulation of stock prices by the defendant. When the representative obtained a settlement of his individual claims, he moved to strike the class claims on the ground that it was impossible to establish the existence of a suitable class. This contention was plainly inconsistent with the representative's assertion for over two years that a proper class existed, and the court rejected it:

It must be presumed, or at least firmly expected, that responsible lawyers, before they put their names to class allegations, will have made some minimally careful explorations to satisfy themselves of the prima facie existence of a class, a claim on behalf of the class, and their suitability to present themselves in the fiduciary role of class representatives. ... In the face of that expectation, and with

88 E.g., Kahan v. Rosenstiel, 424 F.2d 161 (3d Cir. 1970); Rothman v. Gould, 52 F.R.D. 494 (S.D.N.Y. 1971); Yaffe v. Detroit Steel Corp., 50 F.R.D. 481 (N.D. IIl. 1970); Philadelphia Elec. Co. v. Anaconda American Brass Co., 42 F.R.D. 324 (E.D. Pa. 1967). Even where there is no deliberate attempt to circumvent the provisions of rule $23(\mathrm{e})$ it is to be expected that dismissal will occur before the representative has made an "investment" that is so large as to prevent his giving up the suit.

89 See cases cited note 88 supra.

80 52 F.R.D. 494 (S.D.N.Y. 1971). 
no showing either of further researches or of changes in any pertinent circumstances affecting the putative class, counsel will not be allowed to forget the whole business on the mere assertion that it was a mistake to begin with. ${ }^{01}$

Apart from concern about impositions on the courts, District Judge Frankel noted that the bringing of the suit may have deterred "the institution of suits by members of the ostensible class" and that "[t]he passage of time may impair or defeat the rights of others thus deflected from acting for themselves." 92 In the light of the responsibilities the representative had undertaken, the court said: "It is necessary at least that some decent notice be given to those plaintiff purported to represent so that such members of what was once said to be a 'class' may appear, if they wish, to oppose the present application, seek to be substituted as representatives or take other steps appropriate for protection of their interests." voking their settlement offer, and the plaintiff quickly reverted to his original assertion that a class action might be maintained and that he intended to prosecute it vigorously. In spite of the plaintiff's assurances, the court noted that his prior actions cast serious doubt on the quality of representation he would provide in the future and said that "it is possible that some other or others could properly fill that role." court, pursuant to its authority under rule $23(\mathrm{~d})(2)^{95}$ to make orders for the protection of the class, ordered that notice be published in the New York Times and the Wall Street Jourrial, directed toward obtaining others to fill the representation gap. This notice was required even though the action had not yet been certified as a class action..$^{96}$ The court stated that "interdependence of the individual settlement and a class dismissal must be deemed always suspect, and perhaps never suitable." 97

Counsel in Rothman objected that the notice directed by the court

01 Id. at $495-96$.

92 $I d$. at 496.

93 Id.

94 Id. at 498.

95 Rule 23(d)(2) provides: "[T] he court may make appropriate orders: . . . (2) requiring, for the protection of the members of the class or otherwise for the fair conduct of the action, that notice be given in such manner as the court may direct to some or all of the members of any step in the action, or of the proposed extent of the judgment, or of the judgment, or of the opportunity of members to signify whether they consider the representation fair and adequate, to intervene and present claims or defenses, or otherwise to come into the action ...."

96 Two years had passed since the filing of the suit without the court's having determined that the action could indeed be maintained as a class action.

97 52 F.R.D. at 500-01. 
was nothing more than a solicitation of claims. The court correctly rejected this argument. Notice in such situations is necessary to preserve the rights of the class members, to prevent their being deprived of the opportunity to assert their rights because apparently adequate representation turned out to be otherwise. ${ }^{88}$

As the Rothman decision emphasized, brief published notice can protect the interests of the class by bringing in a new representative of the interests of the class. Even abbreviated notice, by informing the members of the bar and the interested class members of the dismissal, should ensure that a substitute class representative will be provided where the class claims are meritorious, thereby rectifying any harm that may have been done by the faintheartedness or bad faith of the original representative. Such notice should do much to protect the interests of class members and may prevent strike-suiting and collusive settlements; a defendant will gain nothing from a collusive settlement with the representative if the class suit is continued by another representative.

Several additional problems not sufficiently considered by the Rothman court must be examined: (1) the effect of the statute of limitations on those who receive such notice; (2) whether a different rule ought to exist when it clearly appears that the claim is without merit; (3) whether a different rule ought to exist where the remedy sought is injunctive or declaratory relief; (4) who should bear the costs of notice; and (5) whether a different rule ought to exist where court-directed notice of the maintenance of the suit has been given and reliance on the maintenance of the action is more likely.

The best method for dealing with the statute of limitations problems of involuntary dismissals with notice, as indicated by the earlier discussion of the question, ${ }^{99}$ is a dismissal without prejudice and a reopening or tolling of the statute of limitations for a period of time sufficient to provide an opportunity for the filing of a new action. ${ }^{100}$ Such a procedure would give the new representative freedom to cast the action in the terms he desires and allow him to bring the action in the federal district he considers most convenient. He would thus not be tied to the old, defective litigation. The time provided should be sufficient to

98 The court said, $i d$. at 501 :

What defendants perceive as a "specter" of unnecessary litigation-with plaintiff's more passionate counsel finding himself "shocked by so champertous a notice"seems only a chimera rising in the heat of advocacy. The case is in substance close to the familiar kinds of suits where a settlement or other disposition possibly hurtful to third parties must be publicized sufficiently to confirm or disconfirm such a possibility. Notices of that sort cause trouble, defeat expectations, bring new litigants into court. But nobody supposes they are "champertous" or unnecessary. So much for the supposed ethical solecism the parties now perceive.

99 See text and notes at notes 71-74 supra.

100 This is analogous to the state saving statutes. See discussion at note 72 supra. 
allow the gathering of forces necessary for the initiation of new litigation. Allowance of a period of one year or the time remaining of the original limitation period, whichever is greater, after the giving of notice should provide sufficient time for the filing of a new action and is in accord with the principles underlying statutes of limitations. Claims thus would not be allowed to slumber indefinitely. On the other hand, a defendant who has been made aware that a claim will be asserted against him can not claim impropriety or surprise if an opportunity is given for reassertion of the claim within a strictly limited period of time.

The justification for notice of involuntary dismissals is preservation of the rights of absent class members; this justification itself raises the question of whether notice should be required where the claim presented in class form appears to the court to be without merit. It can be argued that in such a case notice should not be required; if the claim is without merit there are no substantial rights to be protected. This approach, however, would have the disadvantage of involving the court in extended inquiries into the merits of the claim. ${ }^{101}$ In addition, where failure to give notice is due to an incomplete examination by the court of the merits of the claim, further actions by persons who were members of the class and who relied on the class action might be unfairly foreclosed. Finally, a restriction of notice to only those situations where the claims seem to be of merit would allow one last opportunity for strike-suiting and collusive settlements. A collusive settlement could be disguised by the parties through an assertion that developments had made it clear that the class claim was without merit; there would be no one before the court other than the parties to the settlement to contest that assertion.

It has been pointed out that an involuntary dismissal of a class action will prevent absent members of the class from asserting their claims, even if the dismissal is without prejudice, where the statute of limitations has run. One exception to this problem exists where an action seeks injunctive or declaratory relief, for there the wrong is a continuing one. Courts have been especially solicitous of these actions, which nearly always present civil rights claims, permitting liberal intervention $^{102}$ and allowing the representative to continue to represent a class even though his individual claim has been mooted. ${ }^{103}$ This concern,

- 101 Cf. Dolgow v. Anderson, 53 F.R.D. 664 (E.D.N.Y. 1971), aff'd, 404 F.2d 437 (2d Cir. 1972).

102 Norman v. Board of Parole, 458 F.2d 497 (2d Cir. 1972); Washington v. Wyman, 54 F.R.D. 266 (S.D.N.Y. 1971); Gaddis v. Wyman, 304 F. Supp. 713 (S.D.N.Y. 1969).

103 Banks v. Lockheed-Georgia, 46 F.R.D. 442 (N.D. Ga. 1968); Rackley v. Board of Trustees, 238 F. Supp. 512 (E.D.S.C. 1965). See also Torres v. Department of Labor, 318 F. Supp. 1313 (S.D.N.Y. 1970). 
however, need not inspire a requirement of notice of involuntary dismissal designed to obtain intervenors, for should such an action be involuntarily dismissed without prejudice, a new claim may be presented at any time by an aggrieved member of the class.

A requirement of notice of involuntary dismissal for certain class actions raises the question of who should pay for such notice. The court in Rothman ${ }^{104}$ directed that the defendants should bear the costs of notice. The only discussion of the reasons for this order consisted of the court's noting that if the settlement with the plaintiff were revived "this small item of expense should be easily manageable."105 Although there is authority for imposing on the defendant at least part of the costs of notice of maintenance of the suit as a class action, ${ }^{108}$ this seems unfair except in the rare case where the plaintiff has presented a clearly meritorious claim. Where the plaintiff's claim is fairly debatable the defendant should not be forced to pay for notice to the class. Where notice is to follow an involuntary dismissal that has been produced by either the faithlessness or faintheartedness of the class representative, the case for placing the costs of notice on the representative seems even stronger. It is in this context that the "private attorney general" concept is useful. By making a class allegation, the representative has assumed certain duties to safeguard the interests of the class-among these duties might be included providing notice if the action is to be involuntarily dismissed. The costs of giving notice sufficient to procure an alternative representative, for example by publication in a few select newspapers, will be relatively small; therefore no substantial disincentive to the bringing of a class suit is presented.

Settlement, either secret or openly made subject to rule 23(e), will almost always occur prior to notice to members of the class of the maintenance of the class suit; this analysis has focused on the requirement of notice in this situation. It is also necessary, however, to determine what kind of notice should be required where an involuntary dismissal occurs after notice of the maintenance of the suit. The choice is between the limited notice described above and notice commensurate with that provided the class in informing them of the suit on their behalf. ${ }^{107}$

104 52 F.R.D. 494 (S.D.N.Y. 1971).

$105 \mathrm{Id}$. at 501.

108 See, e.g., Ostapowitcz v. Johnson Bronze, 54 F.R.D. 465 (W.D. Pa. 1972); Bragliani v. Biblowitcz, 13 FED. Rules SERv. 2d 28b.3, Case 8 (S.D.N.Y. 1969).

107 In Mullane v. Central Hanover Bank \& Trust Co., 339 U.S. 306, 315 (1950), the Supreme Court presented what has been interpreted as the standard by which courts are to be guided where due process requires notice, saying:

But when notice is a person's due, process which is a mere gesture is not due process. The means employed must be such as one desirous of actually informing the absentee might reasonably adopt to accomplish it. The reasonableness and hence the Constitutional validity of any chosen method may be defended on the ground 
Given that actual receipt of notice may be expected to induce greater reliance on the part of the represented class, the proper approach should be to require notice commensurate with the previous notice given, based on a presumption that every member of the class has received and relied on notice that the action is being maintained on his behalf.

\section{Gonclusion}

It is clear that if the viability of the class action device is to be preserved, its potential as an instrument for the personal aggrandizement of individual parties must be curtailed and adequate representation of the class ensured. Only by the development of adequate protections for the interests of the members of the class can this be done. Although the problem is susceptible to many solutions-for example, the establishment of some sort of controls over the fees realized by attorneys in class actions-elimination of dismissals with prejudice to absent class members and provision of appropriate notice of involuntary dismissals represent an effort in one part of this developing body of law to prevent the use of the class suit as a device for personal profit.

\section{Michael G. Cleveland}

that it is reasonably certain to inform those affected ... or, where conditions do not reasonably permit such notice, that the form chosen is not substantially less likely to bring home notice than other of the feasible and customary substitutes.

This language has been interpreted as setting up a flexible standard. See, e.g., Snyder v. Board of Trustees, 286 F. Supp. 927 (N.D. III. 1968), where the widespread notoriety the suit had received in the news media was held sufficient to satisfy the requirements of due process. But see Eisen v. Carlisle \& Jacquelin, 41 U.S.L.W. 2586 (U.S. May 8, 1973), where the Second Circuit disapproved a makeshift notice scheme adopted by the district court that had been designed to give notice to a class of 2,250,000 members. The district court opinion is reported at 52 F.R.D. 253 (S.D.N.Y. 1971). 